\title{
The Educational Role of the Family in Enhancing the Intellectual Security of Children
}

\author{
Hend Faye AL-shahrani ${ }^{1, *}$, Mohammad Ahmed Hammad ${ }^{2}$ \\ ${ }^{1}$ Department of Social Planning, Faculty of Social Services, Princess Nourahbint Abdulrahman University, Saudi Arabia \\ ${ }^{2}$ Faculty of Education, Najran University, Saudi Arabia
}

Received August 11, 2020; Revised November 7, 2020; Accepted November 19, 2020

\begin{abstract}
Cite This Paper in the following Citation Styles
(a): [1] Hend Faye AL-shahrani, Mohammad Ahmed Hammad, "The Educational Role of the Family in Enhancing the Intellectual Security of Children," Universal Journal of Educational Research, Vol. 8, No. 12A, pp. 7928-7937, 2020. DOI: 10.13189/ujer.2020.082581.
\end{abstract}

(b): Hend Faye AL-shahrani, Mohammad Ahmed Hammad (2020). The Educational Role of the Family in Enhancing the Intellectual Security of Children. Universal Journal of Educational Research, 8(12A), 7928-7937. DOI: 10.13189/ujer.2020.082581.

Copyright $\subseteq 2020$ by authors, all rights reserved. Authors agree that this article remains permanently open access under the terms of the Creative Commons Attribution License 4.0 International License

\begin{abstract}
Family is the fundamental unit in building strong and cohesive societies. Therefore, it is essential to provide the family with a range of mechanisms and skills that help to fulfill its mandated role by immunizing its children from destructive beliefs. Thereby, the family plays a pivotal role in embodying what is known as intellectual security in society, which is a key factor in flourishing society's progress and prosperity. In addition, It plays a decisive role in society cohesion and pursuit to achieve intellectual security to its children. Therefore, this study aims to investigate the educational role of the family in enhancing the intellectual security of the children in the Saudi society. The sample consisted of (336) parents, aged between (30-60 years), $($ mean $=44.04$, S.D. $=7.42$ ) living in Saudi Arabia. We used the questionnaire developed by researchers, consisting of (36) phrases distributed in three dimensions. The results indicated that the role of parents was in a high level in all dimensions of the questionnaire, Especially, Religious and moral dimension. In addition, Data analysis shows the importance of the educational role of the family in reinforcing the intellectual security of its children in the Saudi society. Based on these results, this study demonstrated the importance of encouraging responsible persons to consider this vital issue with great interests and awareness, and provide full support to Saudi families, helping them to achieve the intellectual security for their children, by increasing security awareness and explaining the dangers of extremism and terrorism to the security. Furthermore, strengthen the intellectual programs, and reduce the obstacles faced by families, and its negative
\end{abstract}

consequences for society.

Keywords Educational Role, Family, Intellectual Security, Children

\section{Introduction}

The family is an important pillar of social security, cultural and intellectual, as the nucleus of society. It is the original corner and safe haven for its children [1]. The role they play in providing comprehensive security to their children, especially intellectual security. The family also plays a pivotal and effective role in the formation of the individual's personality, religious, ethical, intellectual and literary activities [2, 3].

The early years of the individual's life are one of the most important stages, and the most significant influence on the psychological and intellectual aspect. Since the individual's personality is shaped, oriented and inclined, and inculcated the values, customs and traditions of the society to which he belongs $[4,5]$. The more the family is cohesive, interdependent, and committed to moral values and ethics, giving its children a love, a feel of importance, and a stake in decision-making, which this leads to more intellectual stability. It has also succeeded in bringing up its children and protecting them from intellectual drift and sliding in this dangerous path [6, 7].

Mashaqi [8] Confirmed that the family has a major and 
fundamental role, and it is the first role in a true upbringing that brings its children to safety. If the role of the family is absent, the security of its children is gone, and they become the victim of many crimes, foremost among which is the crime of intellectual invasion, that merciless those who are snared in its dens and lost in its darkness [2]. The family must have a set of specifications to enable to carry out its functions and duties. This requires the family to be established on a solid foundation and an adequate educational environment, to release physically, psychologically, mentally, socially and healthy individuals, fortified of extremist ideas and criminal acts of all their forms [6]. This keeps them away from the dangers of intellectual extremism and its consequences [9].

Security is a shared responsibility, and everyone has his role and duty. When individual efforts are integrated with collective efforts, the conditions for security are integrated, which positively affects society and brings prosperity and progress [10]. In its comprehensive concept, security includes many areas: Political security, social security, economic security, health security, food security, intellectual security and human mind. With intellectual security, security is achieved in all other areas, for the close connection between them [11].

Intellectual security is a relatively modern term, although its content is long-standing in cultural heritage. It has received considerable attention recently. In view of the intellectual, political and cultural developments in our Arab and Islamic world [10]. If we look at the challenges in intellectual security, we find it many and varied, and both internal and external, including the common internal and external factors. Examples include ideological, military, psychological and media wars, the development of communications, the information boom, the rise of extremist groups, and economic, social and political conditions [12]. All this represent veritable challenges to intellectual security in our Arab and Islamic societies. Therefore, it can be said that the problem of intellectual deviation is one of the most serious problems facing man's faith and patriotism [13].

Al-Wishahi [14] Show that intellectual security concepts are cumulative concepts that we must pursue to instill in individuals since childhood. Moreover, strive for their continued development and strengthening, in order to confront conflicting intellectual changes [9]. Thereby preventing the dangers of crime, violence and terrorism, which threaten the national security of our societies, taking into account the internal culture of each society, the so-called local culture, which must be preserved from deviant intellectual and cultural influences. Therefore, every individual must be aware of the danger of threatening extremist thought coming through various modern means, whether media, economic or religious [15].

The intellectual invasion is also a social and moral phenomenon suffered by the individual, society and the
State. It reflects a deviation in behavior and thought, one of the direct sources of which may be the violation by the family of its duties and role as the basis for continuous care, education and control [8]. The issue of intellectual security therefore seems to be closely linked to the family, Hence, the family is considered the first preventive channel and indicators of sensing for any threat to its children. As well recognizing the concept of intellectual security and extremis will break the path to the environment in which terrorism and extremism can emerge [16, 17]. This is confirmed [15] pointed out that the family is one of the most important pillars in protecting the intellectual security of its children, as it is the first cell that the child is providing. It is also one of the pivotal social institutions in the development and control of the constructive behavior toward the social life [18]. Hence, there is a close relationship between the family and security, with its material and meaning through the care and upbringing of children, and the achievement of goodwill, sympathy and balanced upbringing that resists all that threatens the integrity of their thought and values [19].

Former literature has pointed out that the family's fulfillment of the intellectual security requirements of its children with dedication via activate dialog among the different parties intellectually, to preserve and reject infringing our cultural heritage, In addition, guide children's use of social networks, try to correct the wrong thinking, to invest leisure time and to develop the values of citizenship [18, 20-22]. Moreover, there are many studies [e.g., 2, 11, 23] Pointed out that the family can gain intellectual security requirements for its children, which is achieved through the promotion of Islamic identity, the promotion of national belonging, the promotion of intellectual security concepts, the enhancement of communication and dialog skills, the development of thinking skills, and the strengthening of technology recruitment controls.

In light of the above, intellectual security in its holistic sense cannot be the responsibility of the security services alone. So, in truth, all society institutions must participate in security, and the most important of these is family. This is because every crime or behavioral aberration is preceded by a kind of intellectual deviation, a lack of thinking, or a lack of education. Thus, attention to so-called intellectual security has increased, seeking to protect thought from any deviation that may become criminal behavior that threatens community or international security. This is what the previous literature has emphasized the importance of the role of community institutions, primarily the family institution in enhancing the intellectual security requirements of their children, which contributes to countering extremism and intellectual terrorism [2, 10, 15, 16, 19, 20, 23, 24].

\subsection{The Current Study}

The family in Saudi society has a pivotal role in 
embodying the so-called intellectual security in society, This is in close association with the Saudi citizen with his family and homeland, and this has an effective role in the socialization of the individual [19]. Thus, if we can provide support to parents, particularly intellectual support, terrorism and extremism can be significantly reduced.

Saudi Arabia is one of the countries that suffered the most damages of intellectual deviation and terrorism recently [25, 26]. It was exposed to an organized terrorist campaign targeting the Saudi society, seeking to provoke sectarian sedition and spread chaos, and seeking to destroy its approach, stability, economy and lifestyle. The Kingdom has been subjected to 128 terrorist offenses since 2001, resulting in, the death and injury of 1,147 citizens, residents and security men, and 14 terrorist acts were carried out in 2015. (8) operations have also been thwarted and (12) terrorist operations have failed. Only 15 military personnel, 6 civilians, 8 military personnel and 24 civilians were injured this year, all because of the intellectual deviation of some individuals in society [27].

The terrorists did not respect the sanctity of time or place inside Saudi Arabia. In Ramadan, 2015, the Prophet's Mosque was subjected to a terrorist operation that resulted in the martyrdom of 5 soldiers and injury of 5 others. The terrorist operation followed the attempt to target the Mecca Mosque in Ramadan in 2016, but was thwarted by security personnel [28]. This makes it imperative that all institutions of society, above all the institution of the family, be united as the first social institution in society. It pursue to develop and control children's behavior toward social life. Furthermore, it aims to establish and activate the centrist and moderate approach of children and to protect them in providing them with comprehensive security, especially intellectual security. This study examines the role of the educational family in fulfilling the requirements of intellectual security of its children. Hence, the study problem can be formulated in the following question: -

Q: What is the educational role of the family in achieving the intellectual security requirements of its children?

\section{Materials and Methods}

\subsection{The Study Method}

Questionnaire based on previous literature review, such as $[15,19,21,23]$. The survey was distributed to the study sample. Then, the data was analysed using statistics

\subsection{Participants}

The study community included all the parents of the students of Princess Nora University and Najran University in Saudi Arabia. A random sample was selected, and was made up of (336) student parents, their ages ranged from 30 to 60 (mean $=41.06$, S.D. $=1.85$ ). Participants were living in Riyadh and Najran, Saudi Arabia.

\subsection{Procedures}

The researchers got approval for this study from the competent authorities in Princess Nora University and Najran University. The sample participants voluntarily filled out the questionnaires without any pressure, and ensuring the confidentiality of the information. The study resolution is distributed to the study sample 350 of the parents participating in this study. Parents have completed the resolution in the website or email (resolution sent home via What's up and email). Fourteen survey forms were excluded because the answers were contrary to the instructions provided with the resolution. As a result, the sample is 336 parents.

\subsection{The Questionnaire}

The researchers in the current study, after reviewing the literature on the role of the family and intellectual security, prepared a questionnaire of three main dimensions, including (36) paragraphs. The first dimension was aimed at identifying the religious and moral role of the family in meeting the requirements of intellectual security, and included (12) paragraphs. The second dimension measures the social and psychological role and consists of (11) paragraphs. The third dimension measures the cultural and intellectual role and consists of (13) paragraphs, the scale of three points (Always - Sometimes- Never) was used. Scores were distributed from 1 to 3, one for " Never " and three for " Always "; the Cronbach Alpha values for the three dimensions were calculated and were $0.82,0.85$, 0.79 , and the scale as a whole was 0.86 .

\subsection{Data Analysis}

To analyze the data of this work, coding and data analysis were carried out using the SPSS Statistics V21 software to perform the statistical analysis. Percentages, frequency, means and standard deviation were calculated for study questions.

\section{Results}

To answer the question study that stated "What is the role of the family educational in achieving the requirements of intellectual security for its children?" means, standard deviations and proportions for participants' responses to items in the first field of the questionnaire were extracted. Table 1 presents the results

Results in Table 1 reveal the high mean score of all 
dimensions in the questionnaire. That is, Families showed a high level of agreement regarding the role of the family education in achieving the requirements of intellectual security for its children. Nearly (90.66) of participants agreed on the importance role of the family in achieving of intellectual security for its children. Moreover, indicators role of the families measurement to achieving the intellectual security for its children ranged between
(88.33\% to $90.0 \%$ ) and the least indicator (88.33\%) was for Social and psychological role while the highest indicator (90.0\%) was for Religious and moral role.

Distribution of participants' responses to items in three dimensions of the questionnaire is shown in tables 2, 3 and 4. Table 2. Show the distribution of participants' responses to the first dimension namely Religious and moral role.

Table 1. Means, Standard Deviations, Percentage and ranking on the Dimensions of questionnaire

\begin{tabular}{|c|c|c|c|c|c|}
\hline & $\begin{array}{l}\text { oles in achieving intellectual security } \\
\text { Sub-Dimensions }\end{array}$ & M & SD & Proportion & Rank \\
\hline 1 & Religious and moral role & 2.76 & 0.21 & $92 \%$ & 1 \\
\hline 2 & Social and psychological role & 2.65 & 0.29 & $88.33 \%$ & 3 \\
\hline 3 & Cultural and intellectual role & 2.75 & 0.30 & $91.66 \%$ & 2 \\
\hline & Total & 2.72 & 0.28 & \multicolumn{2}{|c|}{$90.66 \%$} \\
\hline
\end{tabular}

Table 2. The Distribution of participants' responses to the first dimension namely Religious and moral role.

\begin{tabular}{|c|c|c|c|c|c|c|c|}
\hline & \multirow{3}{*}{ Items (Religious and moral role) } & \multicolumn{3}{|c|}{ Number of respondents and proportion ( \% ) } & \multirow{3}{*}{ M } & \multirow{3}{*}{ SD } & \multirow{3}{*}{$\%$} \\
\hline & & Always & Sometimes & Never & & & \\
\hline & & $\mathrm{N} \quad(\%)$ & $\mathrm{N} \quad(\%)$ & $\mathrm{N} \quad(\%)$ & & & \\
\hline 1 & $\begin{array}{l}\text { I pursuit to be a good example for my children } \\
\text { in words and behavior, especially on the } \\
\text { mental and intellectual side. }\end{array}$ & $284(84.3)$ & $52(15.4)$ & $0(0)$ & 2.84 & 0.36 & 94.66 \\
\hline 2 & $\begin{array}{l}\text { I encourage my children to care about their } \\
\text { values, attitudes, and ideas in their behavior. }\end{array}$ & $264(78.3)$ & $72(21.4)$ & $0(0)$ & 2.78 & 0.41 & 92.66 \\
\hline 3 & $\begin{array}{l}\text { Inculcate my children to do good deeds in } \\
\text { different situations. }\end{array}$ & $256(76.0)$ & $76(22.6)$ & $4(1.2)$ & 2.75 & 0.46 & 91.66 \\
\hline 4 & $\begin{array}{l}\text { Remind my children of the importance of } \\
\text { adhering to religious and ethical values in } \\
\text { interacting with others. }\end{array}$ & $328(97.3)$ & $8(2.4)$ & $0(0)$ & 2.97 & 0.40 & 99.0 \\
\hline 5 & $\begin{array}{l}\text { I advise my children to accept the apology of } \\
\text { others who have abused them. }\end{array}$ & 268 (79.5) & $68(20.2)$ & $0(0)$ & 2.79 & 0.44 & 93.0 \\
\hline 6 & $\begin{array}{l}\text { I equate between my children in their } \\
\text { treatment and adjust between them. }\end{array}$ & $248(73.6)$ & $88(26.1)$ & $0(0)$ & 2. 73 & 0.47 & 91.0 \\
\hline 7 & $\begin{array}{l}\text { I provide the right environment to my children } \\
\text { to gain virtuous values and ethics. }\end{array}$ & $244(72.4)$ & $88(26.1)$ & $4(1.2)$ & 2.71 & 0.58 & 90.33 \\
\hline 8 & $\begin{array}{l}\text { Advice my children use reliable books and } \\
\text { programs sources, which include valuable and } \\
\text { considered religious, ethical and cultural } \\
\text { information that contributes to the formation } \\
\text { of their mind and thought. }\end{array}$ & $176(52.2)$ & $144(42.7)$ & $16(4.7)$ & 2.47 & 0.54 & 82.33 \\
\hline 9 & $\begin{array}{l}\text { I share with children some pictures and videos } \\
\text { which talking about God's love and his } \\
\text { prophet (PBUH), and the moral values are } \\
\text { spread in their souls. }\end{array}$ & $188(55.6)$ & $140(41.5)$ & $8(2.4)$ & 2. 53 & 0.43 & 84.33 \\
\hline 10 & $\begin{array}{l}\text { Within the family, we agree on the same } \\
\text { religious ethical and behavioral principles, } \\
\text { which will infuse them from the ideas coming } \\
\text { and going through the gate of intellectual } \\
\text { invasion. This gives it a little insight through } \\
\text { the gate of intellectual invasion. }\end{array}$ & $252(74.8)$ & $84(24.9)$ & $0(0)$ & 2.75 & 0.25 & 91.66 \\
\hline 11 & $\begin{array}{l}\text { I have established the values of } \\
\text { self-censorship and God's fear in my children } \\
\text { soul in secret and public. }\end{array}$ & $312(92.6)$ & $20(5.9)$ & $4(1.2)$ & 2.91 & 0.31 & 97.0 \\
\hline 12 & $\begin{array}{l}\text { Promote a correct culture of religion that } \\
\text { fosters the values of eternal Islam, } \\
\text { moderation, the introduction of the principle } \\
\text { of moderation, and the rejection of violence, } \\
\text { extremism and gaucheness. }\end{array}$ & $312(92.6)$ & $24(7.1)$ & $0(0)$ & 2.92 & 0.31 & 97.33 \\
\hline & Total & 3132 (77.54) & 864 (21.12) & $43(1.06)$ & 2.76 & 0.21 & 92 \\
\hline
\end{tabular}


Findings in table 2 shows that the relative weight for items in the first dimension namely Religious and moral role was ranging from $(99.0 \%)$ for the phrase that " Remind my children of the importance of adhering to religious and ethical values in interacting with others" to (82.33\%) for the phrase that "Advice my children use reliable books and programs sources, which include valuable and considered religious, ethical and cultural information that contributes to the formation of their mind and thought.". Whilst the relative weight for the whole dimension was (92\%) indicating that importance of religious and moral role in achieving the requirements of intellectual security.
Table 3 reveals that the relative weight of all items in the second dimension "The social and psychological role" ranged between (95.33) for the phrase that "Warn my children not to adopt the method of violence, whether verbal or non-verbal with their different subjects or ideas." And $(78.0 \%)$ for the statement that "I seek to fill my children's leisure time in a healthy and constructive manner, through reading and practicing their hobbies and proper activities." Whereas, the relative weight of the second dimension as a whole was (88.33\%) indicating that importance of social and psychological role in achieving the requirements of intellectual security.

Table 3. The Distribution of participants' responses to items in the second dimension of the first field of the questionnaire namely "The social and psychological role".

\begin{tabular}{|c|c|c|c|c|c|c|c|}
\hline & \multirow[b]{2}{*}{ Items (The social and psychological role) } & \multicolumn{3}{|c|}{ Number of respondents and proportion (\%) } & \multirow[b]{2}{*}{ M } & \multirow[b]{2}{*}{ SD } & \multirow[b]{2}{*}{$\%$} \\
\hline & & $\begin{array}{c}\text { Always } \\
\text { N (\%) }\end{array}$ & $\begin{array}{c}\text { Sometimes } \\
\mathrm{N}(\%)\end{array}$ & $\begin{array}{l}\text { Never } \\
\text { N (\%) }\end{array}$ & & & \\
\hline 1 & $\begin{array}{l}\text { Make my children very confident in their ability } \\
\text { to conduct substantive dialogs and discussions } \\
\text { with others, who are different in some of their } \\
\text { ideas. }\end{array}$ & $236(69.8)$ & $96(28.4)$ & $4(1.2)$ & 2.69 & 0.48 & 89.66 \\
\hline 2 & $\begin{array}{l}\text { Warn my children not to adopt the method of } \\
\text { violence, whether verbal or non-verbal with } \\
\text { their different subjects or ideas. }\end{array}$ & $296(87.6)$ & $36(10.7)$ & $4(1.2)$ & 2.86 & 0.37 & 95.33 \\
\hline 3 & $\begin{array}{l}\text { I reinforce in my children the neutral and } \\
\text { objective approach to the intellectually different } \\
\text { one. }\end{array}$ & $220(65.1)$ & $112(33.1)$ & $4(1.2)$ & 2.65 & 0.49 & 88.33 \\
\hline 4 & $\begin{array}{l}\text { I seek to build social relations among my } \\
\text { children based on honesty, openness, respect, } \\
\text { consultation, and a lasting and continuous } \\
\text { dialog based on persuasion and conviction } \\
\text { within the family. }\end{array}$ & $284(84.0)$ & $52(15.4)$ & $0(0)$ & 2.84 & 0.36 & 94.66 \\
\hline 5 & $\begin{array}{l}\text { Use appropriate, moderate and balanced } \\
\text { treatment methods that are far from (pampering, } \\
\text { cruelty, excessive protection....) And other } \\
\text { irregular methods, which may contribute to the } \\
\text { building of an irregular personality that deviates } \\
\text { from the path of radical thought. }\end{array}$ & $228(67.5)$ & $104(30.8)$ & $0(0)$ & 2.68 & 0.64 & 89.33 \\
\hline 6 & Help my children in choosing the right friends. & $196(58.0)$ & $120(35.5)$ & $20(5.9)$ & 2.53 & 0.60 & 84.33 \\
\hline 7 & $\begin{array}{l}\text { Make my children aware of and immune books } \\
\text { and fatwas, which may conflict with the values } \\
\text { and culture of society. }\end{array}$ & $240(71.0)$ & $92(27.2)$ & $4(1.2)$ & 2.70 & 0.48 & 90.0 \\
\hline 8 & $\begin{array}{l}\text { I seek to fill my children's leisure time in a } \\
\text { healthy and constructive manner, through } \\
\text { reading and practicing their hobbies and proper } \\
\text { activities. }\end{array}$ & $128(37.9)$ & $184(54.5)$ & $16(4.7)$ & 2.34 & 0.57 & 78.0 \\
\hline 9 & $\begin{array}{l}\text { I do my role of supervision over my children, by } \\
\text { following up on children's relations and } \\
\text { friendships, what they see through the media, } \\
\text { and social networking, in order to correct the } \\
\text { wrong behavior that may occur in children in } \\
\text { their early days. }\end{array}$ & $\mathrm{N}=192(56.8)$ & $140(41.4)$ & $4(1.2)$ & 2.55 & 0.52 & 85.0 \\
\hline 10 & $\begin{array}{l}\text { Raise my children on critical thinking, through } \\
\text { which they accept ideas and opinions only after } \\
\text { they have been scrutinized and criticize }\end{array}$ & $212(62.7)$ & $116(34.3)$ & $8(2.4)$ & 2.59 & 0.54 & 86.33 \\
\hline 11 & $\begin{array}{l}\text { I have provide a calm psychological } \\
\text { environment for my children with a peaceful } \\
\text { and without conflict and I support family } \\
\text { cohesion that gives a collective sense. }\end{array}$ & $232(68.6)$ & $100(29.6)$ & $4(1.2)$ & 2.65 & 0.40 & 88.33 \\
\hline & Total & 2464 (66.88) & 1152 (31.27) & 68 (1.84) & 2.65 & 0.29 & 88.33 \\
\hline
\end{tabular}


Table 4. The Distribution of participants' responses to items in the third dimension of the first field of the questionnaire namely "Cultural and intellectual role".

\begin{tabular}{|c|c|c|c|c|c|c|c|}
\hline & \multirow{2}{*}{ Items (Cultural and intellectual role) } & \multicolumn{3}{|c|}{ Number of respondents and proportion (\%) } & \multirow{2}{*}{ M } & \multirow{2}{*}{ SD } & \multirow{2}{*}{$\%$} \\
\hline & & Never & Sometimes & Always & & & \\
\hline 1 & $\begin{array}{l}\text { Raise my children on a culture of } \\
\text { sophistication and dialog with the other, which } \\
\text { is intellectually different. }\end{array}$ & $268(79.5)$ & $68(20.2)$ & $0(0)$ & 2.79 & 0.40 & 93.0 \\
\hline 2 & $\begin{array}{l}\text { I accept new ideas from my children and } \\
\text { discuss them objectively, without minimizing } \\
\text { their disdain. }\end{array}$ & $248(73.6)$ & $88(26.1)$ & $0(0)$ & 2.73 & 0.44 & 91.0 \\
\hline 3 & $\begin{array}{l}\text { Advise my children to receive and refine all } \\
\text { information and ideas, so that they can } \\
\text { differentiate between information and sound } \\
\text { ideas and deviant and extreme ideas. }\end{array}$ & $248(73.6)$ & $88(26.1)$ & $0(0)$ & 2.73 & 0.44 & 91.0 \\
\hline 4 & $\begin{array}{l}\text { Make my children use judging reason and logic } \\
\text { in some ideas, topics, and issues that have been } \\
\text { made public in society. }\end{array}$ & $264(78.3)$ & $68(20.2)$ & $4(1.2)$ & 2.77 & 0.44 & 92.33 \\
\hline 5 & $\begin{array}{l}\text { I infused in my children human values and } \\
\text { principles that promote Islamic and Arab } \\
\text { identity, and the spirit of belonging to God and } \\
\text { then the homeland. }\end{array}$ & $300(89.0)$ & $36(10.7)$ & $0(0)$ & 2.89 & 0.30 & 96.33 \\
\hline 6 & $\begin{array}{l}\text { I attempt to spread the culture of dialog among } \\
\text { my children when talking to them, which } \\
\text { contributes to the exchange of ideas and the } \\
\text { correct modification of their misinformation. }\end{array}$ & $280(83.1)$ & $56(16.6)$ & $0(0)$ & 2.83 & 0.37 & 94.33 \\
\hline 7 & $\begin{array}{l}\text { I seek to spread the spirit of love and } \\
\text { cooperation among my children and keep them } \\
\text { away from the causes of division }\end{array}$ & $292(86.6)$ & $40(11.9)$ & $0(0)$ & 2.87 & 0.33 & 95.66 \\
\hline 8 & $\begin{array}{l}\text { I established in my children the principle of a } \\
\text { sense of responsibility toward the security of } \\
\text { the homeland and the preservation of its } \\
\text { capabilities and gains. }\end{array}$ & $300(89.0)$ & $32(9.5)$ & $4(1.2)$ & 2.88 & 0.35 & 96.0 \\
\hline 9 & $\begin{array}{l}\text { I encourage my children to follow individuals } \\
\text { and scholars who are known to be moderate in } \\
\text { thought. }\end{array}$ & 212 (62.9) & $124(36.8)$ & $0(0)$ & 2.63 & 0.48 & 87.66 \\
\hline 10 & $\begin{array}{l}\text { I encourage my children to participate in } \\
\text { competitions and cultural events that enhance } \\
\text { intellectual security. }\end{array}$ & $172(51.0)$ & 132 (39.2) & $28(8.3)$ & 2.43 & 0.64 & 81.0 \\
\hline 11 & $\begin{array}{l}\text { Teach my children about the human rights } \\
\text { guaranteed by Islam and the Muslim } \\
\text { community. }\end{array}$ & 232 (68.8) & 96 (28.5) & $8(2.4)$ & 2.66 & 0.52 & 88.66 \\
\hline 12 & $\begin{array}{l}\text { Let my children participate in social media, } \\
\text { modern technology, and I ask them to use it } \\
\text { well, to promote the religious and cultural } \\
\text { values of society. }\end{array}$ & $240(71.2)$ & 84 (24.9) & $8(2.4)$ & 2.69 & 0.50 & 89.66 \\
\hline 13 & $\begin{array}{l}\text { Educating my children intellectual and security } \\
\text { furniture to avoid risks and make them aware } \\
\text { of intellectual deviations. }\end{array}$ & 264 (78.3) & $68(20.2)$ & $4(1.2)$ & 2.77 & 0.44 & 92.33 \\
\hline & Total & 332 (76.21). & 980 (22.49) & $56(1.28)$ & 2.75 & 0.30 & 91.66 \\
\hline
\end{tabular}

Table 4 indicates that the relative weight of all items in the third dimension "Cultural and intellectual role" was between (96.33\%) for the fact that "I infused in my children human values and principles that promote Islamic and Arab identity, and the spirit of belonging to God and then the homeland." And (81.0\%) for the statement that "I encourage my children to participate in competitions and cultural events that enhance intellectual security ". Whereas, the relative weight of the second dimension as a whole was (91.66\%) indicating that importance of culture and intellectual role in achieving the requirements of intellectual security.

\section{Discussion}

The results of the field study indicated that the reality of the family's exercise, of its educational role in enhancing the intellectual security was very high in all dimensions of questionnaire. In other words, most Saudi families play their educational roles in enhancing intellectual security in the religious, ethical, social, psychological and intellectual aspects. The religious and ethical dimension has been given the first order of the study responses; the family is one of the most important educational institutions that influence the development of religious and ethical values in their children, and the first educational medium in 
which children learn desired patterns of behavior and social habits through family interaction [19]. The relationships that are formed among members of the family, which have the effect of affecting each other with a view to create new experiences that promote and develop the religious and moral values of the children. This requires the family to carry out their duties toward the education of children in religious and ethical manner. Thereby, contributing to the progress and cohesion of society. In addition, the development of a sense of social responsibility, commitment and internal control, the ethical and religious values are the orientations and energies of individual and collective action, and they control the behavior of individuals and comprise them as social unity. This is reflected in values such as equality, justice, sacrifice, altruism, non-violence, and other values that play a role in the unity and cohesion of society [23]. The paragraph (remind my children of the importance of adhering to religious and ethical values in interacting with others) received the first order in terms of the religious and moral dimensions. Possibly because Saudi society has a special nature, as it is generally a religious society whose members (male and female) respect religious and ethical habits and values; they are also given consideration to the good family traditions on which they have been nurturing. The presence of the two Holy Mosques on Saudi Arabia has undoubtedly granted religious and moral status to this country and its people, who are honored to serve the guests of Makkah. The paragraph (promoting the correct culture of religion that promotes the values of eternal Islam, moderation, the introduction of the principle of moderation, rejection of violence, extremism, and treatise) came second in the first dimension as the Saudi family plays a preventive role of educating children about the dangers of extremism and developing their security sense. The results of this were clear from the results of a study [29]. That raised awareness among young people who are becoming aware of the risks that can be posed to individuals and society as a result of extremism, whether directed toward the individual, the community or society. The results are also consistent with many studies $[18,19$, 30].

The cultural and intellectual dimension came in the second place after the religious and moral dimension. and the most important paragraphs of the cultural and intellectual dimension came from the sample of the study for the phrase "pursuit to infuse the human values and principles of my sons that reinforce the Islamic and Arab identity, and the spirit of belonging to God and then the homeland", where most Saudi families reinforce the Islamic identity [31, 32]. To deepen the belonging to religion, which has become a basic requirement we need, to seek to develop the children's feeling of Islamic identity and the great role they can play in preserve their Islamic identity. The family's quest to develop virtues and ethical values, which are the fruit of faith, is one of the most important roles it seeks to achieve [33, 34]. Thus, they avoid being deviated from all forms of violence, and build their personalities on good and hard work, to achieve intellectual security in themselves by meeting their religious and moral needs, and this leads them to feel values of society, in order to achieve security and stability $[19,20,29]$.

The social and psychological dimension has also been arranged in the third and last order at the level of the three dimensions. However, it has received a high mean, which indicates the importance the family attaches to the proper social and psychological recovery of its children. As the formation of social behavior starts from the surroundings of the human being who interacts with it [35]. The importance of psychosocial life, as a key component of successful relationships and interactions with others, must be emphasized, starting from childhood [36-38]. A large proportion of a child's perception of future life is determined by his or her childhood. Therefore, affects his or her treatment, thinking and attitudes toward others. The social and psychological upbringing of their children has a great impact on their social control process, the respect for values, systems, steering thought and behavior, the training of children since its inception in commitment to social values, sound psychological upbringing, respect for systems and the rights of others. This contributes significantly to the construction of a well-founded preventive system to address violence and terrorism and to enhance the intellectual security of children. The phrase (warn my children not to adopt the style of violence, whether verbal or non-verbal, with the different people on some subjects or ideas) was arranged in the first order between the social and psychological dimension phrase, as Saudi families seek to reinforce the culture of discussion and dialog among their children. To train children to listen to other opinions, to respect their opinions and ideas, and to discuss them through dialog, parents begin by discussing children in their views and ideas even if they are contrary to their views, and also to allow children to discuss each other away from violence and abuse [2, 23].

\section{Conclusions}

The paper reviewed the results of the research on the educational role of the family in enhancing the intellectual security of the children, by measuring the roles of the Saudi family in achieving the intellectual security of their children. These measures have been applied to a group of working parents at Princess Nora University and Najran University, and the main contribution to this research is that it provides a deeper understanding of the role that families in Saudi Arabia play in enhancing their children's intellectual security, In particular, in Saudi Arabia. Thus, the study attempted to highlight the importance of the role of the family in enhancing the intellectual security of its 
children. The importance of fortification of children, which begins with intra-family education by encouraging dialog and persuasion, discussion, cultural and intellectual awareness, promoting religious and ethical values, and linking children to Quran and Sunna of prophet, to the same as children full with kindness, healthy psychological and social development, and care for life requirements.

Then improved conscious surveillance in adolescence and youth, to know what to read and do online, TV channels and their friends, where to spend their free time, seek to correct children's mistakes early, and guide them to the right direction, before the matter gets worse, and find children involved in a terrorist crime. Is it reasonable to be surprised to a parent that his son is involved in a terrorist crime and is wanted by the security services through the mass media without having seen a sign that he is on this path before that?

Therefore, the father must be aware of his role in trapping this astray thinking, before he is surprised that his son or daughter has fallen prey to it; and may have caused innocent victims, who are not guilty. If we do not, we may be surprised at some time by the fact that this astray thinking applies to our children, and if that happens, we can only feel guilty, and perhaps collaborates in the sinner.

We hope that the results of this research will encourage officials to look at this vital issue in greater depth, and provide full support to Saudi families in order to help them achieve intellectual security requirements for their children. By raising security awareness among parents and children and explaining the dangers of extremism and terrorism to the security of society, An integrated intellectual system is being built, based on the consolidation of the tenets of moderation in beliefs, deeds and words. In addition, families continue to pursue their children's affairs, in order to protect them from the dangers of intellectual extremism, to strengthen the intellectual programs of families and children, and to reduce the obstacles that families face in order to achieve intellectual security requirements and its negative consequences on the social and security aspects. This helps specialists and officials to contribute to reducing these negative effects on Saudi society.

\section{Limitations and Recommendations of the Study}

We must acknowledge that there are some limitations in this research study; the study is limited to examining the educational role of the family in enhancing the intellectual security of children. In addition, the sample size is relatively small, which may restrict this study from reaching convincing results, therefore, it cannot be generalized. In addition, the study did not specify which Parenting styles that directly affect intellectual security.
As well, this study did not consider other important aspects that affect intellectual security such as schools, university, Society's culture, poverty, and educational media. Finally, the dissemination of the results is viable only for populations that have been drawn from equivalent communities. It is suggested for future studies to set a larger sample size in order to acquire information that is more reliable and ensure generalizability of the findings. In addition, there are some suggested future studies such as the educational role of the educational institutions in enhancing the intellectual security of children; the relationship between emotional intelligence and intellectual security among university students. In addition, Building dialogue platforms for schools and university students with content, academic activities and enrichment to develop their knowledge and intellectual and linguistic skills.

\section{Funding}

The research was fund by Center for Promising Research in Social Research and Women's in Princess Nourah bint Abdulrahman University in Kingdom of Saudi Arabia.

\section{Acknowledgments}

We are thankful for Funding by Center for Promising Research in Social Research and Women's in Princess Nourah bint Abdulrahman University in Kingdom of Saudi Arabia.

\section{Conflicts of Interest}

The authors declare no conflict of interest.

\section{REFERENCES}

[1] E. M. Forman, and P. T. Davies, “Assessing children's appraisals of security in the family system: The development of the Security in the Family System (SIFS) scales," Journal of Child Psychology and Psychiatry, vol. 46, no. 8, pp. 900-916, 2005.

[2] K. F. A. Rahamneh, and M. A. H. Al-Qudah, “A Proposed Educational Vision for Activating the Role of The Jordanian Universities Students Families in Enhancing Students Intellectual Security from the Students Perspectives," European Scientific Journal, vol. 12, no. 16, 2016.

[3] F. Santoso, M. Mulyoto, D. Djono, and M. Hanif, "Inculcating Character Values to the Student of Polytechnic ATMI Surakarta Vocational School," Universal Journal of Educational Research, vol. 8, pp. 79-89, 03/01, 2020. 
[4] J. L. Cabaj, S. W. McDonald, and S. C. Tough, "Early childhood risk and resilience factors for behavioural and emotional problems in middle childhood," BMC pediatrics, vol. 14, no. 1, pp. 166, 2014

[5] M. Ahmed Hammad, and H. Shaaban Awed, "Prevalence of Cyberbullying and Traditional Bullying and Their Relationship to Self-Esteem among Hearing-Impaired Adolescents," Humanities \&amp; Social Sciences Reviews, vol. 8, no. 2, pp. 167-178, 09/27, 2020.

[6] J. E. Grusec, "Socialization processes in the family: Social and emotional development," Annual review of psychology, vol. 62, pp. 243-269, 2011.

[7] H. F. AL-shahrani, and M. A. Hammad, "The Role of Voluntary Work in the Improvement of The Social Capital and Sustainable Development in Saudi Society," Humanities \& Social Sciences Reviews, vol. 7, no. 5, pp. 1104-1120, 2019.

[8] A. Mashaqi, "Family and intellectual security," Security and Life Journal, vol. 390, no. 34, pp. 26-31, 2014.

[9] I. Sharifin, and A. Matalqa, "Family rehabilitation mechanisms to achieve psychological and intellectual security for children.,” The Arab Journal of Security Studies and Training, vol. 30, no. 60, pp. 87-131, 2014.

[10] D. Waswas, and A.-M. M. Gasaymeh, "The Role of School Principals in the Governorate of Ma'an in Promoting Intellectual Security among Students,” Journal of Education and Learning, vol. 6, no. 1, pp. 193-206, 2017.

[11] W. Al-Otaibi, "The extent of the contribution of female scientific majors to providing intellectual security requirements for high school students from the teachers point of view in Riyadh," Educational Journal and Psychological Sciences, vol. 25, no. 3, pp. 1-20, 2017.

[12] H. A. Al-Dajah, "Contemporary Theory of Intellectual Security,” Canadian Social Science, vol. 15, no. 3, pp. 11-22, 2019.

[13] Y. D. Al-Khataibeh, "Social media-extremism ideas as an intellectual security threat: A case study of Jordanian university undergraduates,” British Journal of Humanities \& Social Sciences, vol. 18, no. 1, pp. 34-47, 2017.

[14] G. Al-Wishahi, "The role of the College of Education in achieving intellectual security for its students: a field study," Journal of the Faculty of Education, Assiut, vol. 31, no. 3, pp. 478-551, 2015.

[15] B. Al-Hajj, “The role of the family in achieving intellectual security within Algerian society," Journal of Law and Humanities, vol. 9, pp. 165-187, 2011.

[16] A. A. A. Hamidi, "The family's contribution to achieving intellectual security: an Islamic educational vision," The Arab Journal of Security Studies and Training, vol. 61, no. 30, pp. 117-155, 2014.

[17] D. Koehler, "Family counselling, de-radicalization and counter-terrorism: the Danish and German programs in context," Countering violent extremism: developing an evidence-base for policy and practice, pp. 129-138, 2015.

[18] Fatima Zine El Abidine, "The role of the family and civil society institutions in preventing extremism and terrorism,"
Journal of Education, Al-Azhar University, vol. 163, no. 3 pp. 685-723, 2015.

[19] N. Al-Ali, "The role of the family in intellectual extremism and its relationship to achieving social security," Journal of Arab Studies, vol. 36, no. 2, pp. 969-1006, 2017.

[20] A. H. Ali, “The family's contribution to achieving intellectual security: an Islamic educational vision," The Arab Journal of Security Studies and Training, vol. 61, no. 30, pp. 117-155, 2014

[21] A.-H. Hakim, "The role of the family in achieving security," Security Research Journal, vol. 38, no. 16, pp. 83-143, 2006.

[22] M. Al-Thuwaini, and A. N. Muhammad, "The role of the university teacher in achieving the intellectual security of his students in light of the implications of globalization," Journal of Educational and Psychological Sciences, vol. 7, no. 2, pp. 957-1050, 2014.

[23] K. Yassin, "The role of the family in raising its children on safe thinking," The Educational Journal, vol. 54, pp. 37-64, 2018.

[24] P. Upali, Role of family as a social institution on children's wellbeing in the contemporary Sri Lankan Society, 2015.

[25] A. Gendron, "Confronting Terrorism in Saudi Arabia," International Journal of Intelligence and Counter Intelligence, vol. 23, no. 3, pp. 487-508, 2010.

[26] R. Meijer, N. Hasan, B. Hendriks, and F. Janssen, Counter-Terrorism Strategies in Indonesia, Algeria and Saudi Arabia, Netherlands Institute of International Relations' Clingendael', 2012.

[27] A. R. Morgan. "Changing the strategy of ISIS and Qatif cells: indicators of terrorism in Saudi Arabia in 2016," 10/4/2020, 2020; http://www.okaz.com.sa/article/1519692

[28] B. Hubbard, "Suicide Bombings Hit 3 Cities in Saudi Arabia, One Near a Holy Site,” New York Times, vol. 4, 2016.

[29] A. Al-Bakkar, and Y. Khattabiyya, "Factors Leading to Extremism in the Family and Ways to Immunize Children from the University Youth Viewpoint at Al-Balqa Applied University: A Sociological Study,” Journal of the Islamic University for Humanitarian Research, vol. 26, no. 2, pp. 480-506, 2018.

[30] R. Borum, "Psychological vulnerabilities and propensities for involvement in violent extremism," Behavioral sciences \& the law, vol. 32, no. 3, pp. 286-305, 2014.

[31] T. Elyas, and M. Y. Picard, "Teaching and moral tradition in Saudi Arabia: a paradigm of struggle or pathway towards globalization?,” Procedia-Social and Behavioral Sciences, vol. 47, pp. 1083-1086, 2012.

[32] M. Yamani, Cradle of Islam: The Hijaz and the quest for an Arabian identity: Bloomsbury Publishing, 2009.

[33] M. Duh, J. Belak, and B. Milfelner, "Core values, culture and ethical climate as constitutional elements of ethical behaviour: Exploring differences between family and non-family enterprises,” Journal of business ethics, vol. 97, no. 3, pp. 473-489, 2010.

[34] L. Gloyn, The ethics of the family in Seneca: Cambridge University Press, 2017. 
[35] E. Staub, Positive social behavior and morality: Social and personal influences: Elsevier, 2013.

[36] B. M. Newman, and P. R. Newman, Development through life: A psychosocial approach: Cengage Learning, 2017.

[37] M. A. Hammad, "Future Anxiety and Its Relationship to Students' Attitude toward Academic Specialization,"
Journal of Education and Practice, vol. 7, no. 15, pp. 54-65, 2016.

[38] J. Budiwan, F. Hidayatullah, M. Yusuf, and A. Asrowi, "Validity Test of the Family Supported Collaborative Learning (FSCL) Model to Instill Character Values to Junior High School Students," Universal Journal of Educational Research, vol. 8, pp. 1-6, 03/01, 2020. 